\title{
THE CONDITIONS OF 'SAVAGES'? STATELESSNESS, POLITICS AND RACE IN HANNAH ARENDT'S THE ORIGINS OF TOTALITARIANISM
}

\author{
MICHIEL BOT
}

\begin{abstract}
This article explores the ways in which race enters our analyses of statelessness when we build those analyses (partly) on Hannah Arendt's arguments in 'Imperialism'. Through close readings of Arendt's ambivalent use of race in this text, the article demonstrates that critically confronting Arendt's repeated comparison of stateless people to 'barbarians' and 'savages' is useful for confronting the connections between statelessness, politics and race in the present. The article argues that such a critical confrontation can yield three things. First, the realisation that thinking through the politics enacted by de jure or de facto stateless people who have been forced to live in the conditions of 'savages' requires that we situate this politics within the history of imperialism and post-colonialism. Second, an awareness of the need to consider the connections between the political production of statelessness and the political production of race. And third, the realisation that an effective politics of people who have been forced into de jure or de facto statelessness must include a politics of anti-racism.
\end{abstract}

\section{TABLE OF CONTENTS}

I Introduction 195

II The Argument of 'Imperialism' 197

III Political Mechanisms of Dehumanisation: Arendt's Ambivalence about 'Savages'

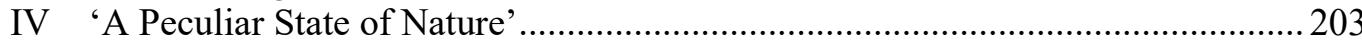

V Thinking the Politics of Countering Statelessness with Arendt against Arendt: The Dark Background of Mere Givenness .........................................................2206

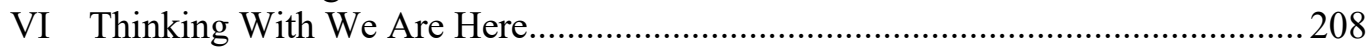

\section{INTRODUCTION}

Since the 1990s, ch 9 of Hannah Arendt's The Origins of Totalitarianism has been a locus classicus for scholars of statelessness, who keep returning to its analysis of the predicament of stateless people and refugees as a condition of exclusion from political participation, its critique of human rights and its famous conception of a 'right to have rights'. ${ }^{1}$ However, these scholars have paid little attention to Arendt's repeated comparison of stateless people and refugees to 'barbarians' and, of their conditions, to the conditions of 'savages'. This lack of attention is surprising, because ch 9 is the culmination of a 180-page analysis of European imperialism (Part 2 of The Origins of Totalitarianism, which was also published

* I would like to thank the anonymous reviewers for their thorough engagement with this article. I would also like to thank my colleagues in the Jurisprudence and Legal Philosophy research seminar at Tilburg University for their comments, as well the audience of the 2018 conference of the Association for Political Theory at Haverford and Bryn Mawr colleges, where I presented an earlier version of this article. Above all, I would like to thank the members of We Are Here, especially Hashim, for discussing their experiences and their politics with me, and for their hospitality.

1 Hannah Arendt, The Origins of Totalitarianism (Harcourt Brace Jovanovich, new ed, 1976) ch 9. 
separately, titled 'Imperialism'), in which 'savages' and 'barbarians' figure prominently and in which the concept of race plays a central role. ${ }^{2}$ But this lack of attention to Arendt's comparison is also surprising given the central role that race often plays in policies and discourses about stateless people and refugees. ${ }^{3}$ Although Arendt's writings on race have been the topic of a heated debate in Arendt scholarship since the 1990s, Arendt scholars have seldomly connected this debate to Arendt's analysis of statelessness. ${ }^{4}$

The purpose of this article is not to either 'defend' or 'condemn' Arendt for her writings on race, let alone to question her 'private ethics'. ${ }^{5}$ Instead, this article seeks to explore the ways in which race enters - as well as the ways in which race does not enter - our analyses of statelessness when we build those analyses

$2 \quad$ See ibid pt 2 ch 5-9.

3 Various scholars have recently pointed out that the role of race in policies and discourses about refugees remains underexplored in the field of migration studies. Cf Alana Lentin, Darshan Vigneswaran, Saskia Bonjour and Amade M'Charek, 'What's the Use of Race in Migration Studies' (Workshop, University of Amsterdam, 1 October 2018). Romit Bhandari also commented on the lack of attention to race in the study of refugee law in his presentation: 'International Refugee Law's Cyclical Dialectics: Between Universality and Eurocentrism' (Presentation, 2018 Critical Legal Conference, Open University, 6 September 2018). However, several scholars gave presentations on the connections between refugee law, refugee policing, and race at a conference on 'Racial Orders, Racist Borders' organised by the Amsterdam Centre for Globalisation Studies on 17-18 October 2019.

4 An early, polemical intervention in this debate was Anne Norton's 1995 article: 'Heart of Darkness: Africa and African Americans in the Writings of Hannah Arendt' in Bonnie Honig (ed) Feminist Interpretations of Hannah Arendt (Pennsylvania State University Press 1995), 247. Taking issue with what she called the 'generous' interpretations of Arendt's treatment of European racism in The Origins of Totalitarianism by George Kateb, Lisa Dish and Seyla Benhabib ('Arendt's defenders'), Norton argued that there is in fact an 'uneasy fit between [Arendt's] writings on race and her disavowal of complicity in an unjust racial order', and that

her constructions of Africans and African Americans, her forgetfulness of Asians, and her efforts to sequester racism in the South do not subvert or depart from what she called 'the common prejudices of Americans in this area'.

At 248. See also George Kateb, Hannah Arendt: Politics, Conscience, Evil (Rowman and Allanheld 1983) 61-63. For Benhabib's response to Norton, see Seyla Benhabib, The Reluctant Modernism of Hannah Arendt (Rowman \& Littlefield 2003) 86. The debate about Arendt's writings on race continues to this day. See, for instance, the volume, Richard H King and Dan Stone (eds), Hannah Arendt and the Uses of History: Imperialism, Nation, Race, and Genocide (Berghahn 2007); Michael Rothberg, 'At the Limits of Eurocentrism: Hannah Arendt's The Origins of Totalitarianism' in Multidirectional Memory: Remembering the Holocaust in the Age of Decolonization (Stanford University Press 2009); Jimmy Casas Klausen, 'Hannah Arendt's Antiprimitivism' (2010) 38(3) Political Theory 394; Kathryn T Gines, Hannah Arendt and the Negro Question (Indiana University Press 2014). See especially Shmuel Lederman, 'Making the Desert Bloom: Hannah Arendt and Zionist Discourse' (2016) 21(4) The European Legacy 393, which discusses Arendt's early justification of Zionism through the colonialist trope of cultivating the land.

5 These issues are at the centre of some of the polemics about Arendt's writings on race. For instance, Norton writes:

I am concerned not with Arendt's private ethics, but with the racial politics expressed in a body of canonical writings, and the strategies of denial that haunt the politics of race in America. Yet this essay may call Arendt's private ethics into question. I regret that, but I find the reasons for writing outweigh the reasons for silence.

Norton (n 4) 248. The primary concern of Norton's article is the 'unjust effects' of 'Arendt's statements on Africans and African Americans', for instance 'when we place Arendt's writings on race before our students and our readers, without question or remark, in an attitude of respect and veneration': at 248. 
(partly) on Arendt's arguments in 'Imperialism'. ${ }^{6}$ I will argue that if we want to use Arendt's arguments to imagine a politics of stateless people that is not a contradiction in terms - that is, a politics of those whose predicament is that they have been excluded from politics - it is crucial to confront the role that race plays in these arguments. I will make a case for thinking the relationship between statelessness, politics, and race 'with Arendt against Arendt', taking Arendt's repeated comparison of stateless people to 'savages' and 'barbarians' more seriously than Arendt does herself, by reading the passages where Arendt suggests that 'savages' and 'barbarians' are categories of political exclusion produced by European racism against the passages where Arendt uncritically uses 'savages' and 'barbarians' as ahistorical, paradigmatic examples of rightlessness.

I aim to demonstrate that critically confronting Arendt's comparison of stateless people to 'barbarians' and 'savages' is useful for confronting the connections between statelessness, politics and race in the present. I will argue that such a critical confrontation can yield three things. First, the realisation that thinking through the politics enacted by de jure or de facto stateless people who have been forced to live in the conditions of 'savages' requires that we situate this politics within the history of imperialism and post-colonialism. Second, an awareness of the need to consider the connections between the political production of statelessness and the political production of race. And third, the realisation that an effective politics of people who have been forced into de jure or de facto statelessness must include a politics of anti-racism.

The article consists of five Parts. Part II provides an overview of 'Imperialism' in order to situate ch 9 within the context of Arendt's larger argument about law and politics after imperialism. Parts III, IV, and V develop a critical analysis of Arendt's ambivalent use of race, by means of close readings of passages from ch 7 and 9. Part VI switches gears to discuss the politics of Amsterdam-based refugee collective We Are Here, which has been struggling against the legal and political exclusion of 'undocumented' people by the Dutch state, as well as protests by antiimmigrant activists since 2012. I will show why it is useful to return to Arendt's analyses to makes sense of such examples of refugee politics in the present, but only if we critically confront Arendt's comparison of stateless people to 'barbarians' and 'savages'.

\section{ThE ARGUMENT OF 'IMPERIALISM'}

Because Arendt's diagnosis, in ch 9, of the predicament of stateless people in the mid-twentieth century is the culmination of her analysis of the nation-state in an age of imperialism, it is important not to read this chapter out of context, or to interpret it as an abstract, normative political theoretical argument, but to read it in the context of 'Imperialism' as a whole. 'Imperialism' traces what happens to spaces for politics and law after nation-states, the form that such spaces took in a considerable part of Europe after the Peace of Westphalia, expanded into empires because '[t]he ruling class in capitalist production came up against national

6 While most other commentators have sought to extract Arendt's views on race from different texts, I deliberately limit my analyses to 'Imperialism', not only because it was published as a free-standing text, but also because it is by far Arendt's most rigorous and extended engagement with the concept of race and because I am interested in the connections between Arendt's writings on statelessness, politics, and race in that text. For a comprehensive analysis of Arendt's views on race in general that gives relatively little attention to 'Imperialism', see Gines (n 4). 
limitations to its economic expansion' ${ }^{7}$ At the beginning of 'Imperialism', Arendt contrasts the imperialist 'expansion' of European nation-states - especially after the 1884 Berlin Conference — to the 'conquests' of earlier empires:

Conquest as well as empire building had fallen into disrepute for very good reasons. They had been carried out successfully only by governments which, like the Roman Republic, were based primarily on law, so that conquest could be followed by integration of the most heterogeneous peoples by imposing upon them a common law. The nation-state, however, based upon a homogeneous population's active consent to its government ('le plebiscite de tous les jours'), lacked such a unifying principle and would, in the case of conquest, have to assimilate rather than to integrate, to enforce consent rather than justice, that is, to degenerate into tyranny. ${ }^{8}$

The French parenthesis ('the daily plebiscite') is a reference to Ernest Renan's 1882 essay, What is a Nation?. ${ }^{9}$ Renan's main argument in that essay was that a nation is not a 'natural' unit defined by language, religion, or race, but an artifice that needs to be continually reconstituted through the consent of the members of the national community, a consent to sharing a 'rich legacy of memories', 10 a 'soul', 11 a 'spiritual principle', 12 or a 'moral consciousness',13 and a consent to sacrifice, if necessary, their lives for that 'soul'. ${ }^{14}$ Renan strongly opposed the substitution of an 'ethnographic principle ... for a national one', 15 which he considered 'a very great error, which, if it were to become dominant, would destroy European civilization'. ${ }^{16}$ According to Arendt, this is exactly what happened to European nation-states when they expanded beyond the limits of their European territory: the degeneration of a voluntarist, cultural and moral conception of the nation, first into what Renan called an 'ethnographic' conception and which might today be called cultural essentialism, and finally into a biological, racial one. ${ }^{17}$

Arendt thus follows Renan's analysis of what a nation is, as well as Renan's analysis of the pitfalls of a nation. However, Arendt strongly disagrees with Renan's optimistic belief in the possibility of applying the nation principle universally and consistently. For Renan naively writes: 'If doubts arise regarding its [a nation's] frontiers, consult the populations in the areas under dispute'. ${ }^{18}$ By contrast, Arendt argues in 'Imperialism' that the idea that each national community can have its own state on its own territory was always a fantasy, even if the calamitous consequences of this fantasy only manifest themselves in the twentieth century with the outbreak of World War I, the collapse of the AustroHungarian, Russian and Ottoman Empires, and the partition of Europe into new

Arendt, The Origins of Totalitarianism (n 1) 125.

ibid 125 (citations omitted).

Ernest Renan, 'What is a Nation?', tr Martin Thom in Homi K Bhabha (ed), Nation and Narration (Routledge 1990) 8.

10 ibid 19.

11 See ibid 18.

12 ibid.

13 ibid 20

14 ibid

15 ibid 13.

16 ibid.

17 Arendt briefly discusses Renan's writings on race. See Arendt, The Origins of Totalitarianism (n 1) 174, 242.

18 Renan (n 9) 20. 
nation-states that produce a massive amount of people who do not 'belong' to the nation of the nation-state in which they live.

According to Arendt, the Roman Empire could integrate the peoples it conquered by making them legal subjects under a law that was universal rather than an expression of a Roman 'nation'. ${ }^{19}$ Arendt develops this argument further in a section on 'The Question of War' in her unfinished Introduction into Politics, which she started in 1955. ${ }^{20}$ In that text, Arendt argues that Rome's political principle was one of 'making treaties and forming alliances', ${ }^{21}$ so that 'for the Romans, politics began as foreign policy, that is, as the very thing the Greek mind had completely excluded from politics'.22 Idealising Roman expansion in a way that historian A Dirk Moses sees as a continuation of the reception of Marcus Tullius Cicero by Renaissance thinkers such as Niccolò Machiavelli and James Harrington, ${ }^{23}$ Arendt argues that the Romans aimed not for an 'Imperium Romanum' but for a 'societas Romana, an infinitely expandable system of alliances initiated by Rome'. ${ }^{24}$

By contrast, Arendt argues in 'Imperialism', when nation-states expanded into empires, the legal integration of conquered peoples was structurally impossible, because: 'The nation ... conceived of its law as an outgrowth of a unique national substance which was not valid beyond its own people and the boundaries of its own territory'. ${ }^{25}$ Therefore, European imperialists ruled over their colonies through violence, bureaucratic decrees and racism, not law, treating their colonial subjects as labour power to be exploited and populations to be managed, and reducing government to a police force securing the business interests of the imperialist bourgeoisie.

Arendt's argument is that this imperialist expansion of the nation-state destroyed politics and law not only in the colonies, but also in Europe. Just as Aimé Césaire, in his 1950 Discourse on Colonialism, considered Nazism to be a 'choc en retour', a shock in reverse, of racist dehumanisation pioneered in the colonies, ${ }^{26}$ Arendt, writing around the same time, saw Nazism as the culmination of the destruction of politics and law that has its origins in the principle of the nation-state, but only fully manifests itself under imperialism:

African colonial possessions became the most fertile soil for the flowering of what later was to become the Nazi elite. Here they had seen with their own eyes how peoples could be converted into races and how, simply by taking the initiative in the process, one might push one's own people into the position of the master race. ${ }^{27}$

Arendt's argument about 'the boomerang effect of imperialism upon the homeland'28 draws inspiration from Edmund Burke's warning about the

19 See Arendt, The Origins of Totalitarianism (n 1) ch 9.

20 A draft of this text was published in Jerome Kohn (ed), 'Introduction into Politics' in Hannah Arendt, The Promise of Politics, ed Jerome Kohn (Schocken 2005) 93, 153-191 (emphasis in original).

21 ibid 185.

22 ibid 183.

23 A Dirk Moses, 'Das römische Gespräch in a New Key: Hannah Arendt, Genocide, and the Defense of Republican Civilization' (2013) 85(4) The Journal of Modern History 867, 886.

24 Kohn (n 20) 186.

25 Arendt, The Origins of Totalitarianism (n 1) 127.

26 Aimé Césaire, Discourse on Colonialism, tr Joan Pinkham (Monthly Review Press 2000). For a sophisticated comparison with Arendt's 'Imperialism', see Rothberg (n 4).

27 Arendt, The Origins of Totalitarianism (n 1) 206.

28 ibid 155. 
corrupting, violent interactions between the English and their colonial subjects: Arendt repeatedly cites Burke's warning that "the breakers of the law in India" might become "the makers of law for England". 29

Arendt's diagnosis, in ch 9, of the predicament of stateless people, refugees, and minorities in the mid-twentieth century is the culmination of this analysis of the nation-state in an age of imperialism. Arendt's argument in the first half of ch 9 is that because nation-states are the states of culturally, linguistically, religiously, ethnically and/or racially homogeneous nations, they inevitably produce an excess of outsiders who live on their territory but do not belong to these nations and cannot be assimilated by them. This structural political flaw of the principle of the nation-state did not manifest itself (historically) until after World War I, when new nation-states proliferated after the collapse of the Austro-Hungarian, Czarist and Ottoman empires. For instance, the creation of a Polish nation-state produced an excess of Russians and Jews who did not belong to the Polish nation; 30 the creation of Turkey produced an excess of Armenians, Greeks and Kurds. ${ }^{31}$ The production of inassimilable excess populations was accelerated after World War II, when the collapse of the Western-European colonial empires caused an even greater proliferation of new nation-states. For instance, the creation of a Jewish nation-state produced an excess of Palestinians; ${ }^{32}$ the creation of an Indian nationstate produced an excess of Muslims. ${ }^{33}$ Whereas stateless people and refugees in earlier centuries could found new political communities elsewhere, Arendt argues the predicament of stateless people and refugees in the mid-twentieth century is that the entire globe is occupied by a closed system of nation-states, so that there is nowhere else to go. Political structures like the European Union have arguably exacerbated the problem diagnosed by Arendt: because European Union citizenship is linked to national citizenship, exclusion from national citizenship also means exclusion from EU citizenship. ${ }^{34}$

\section{Political Mechanisms of Dehumanisation: Arendt’s Ambivalence}

\section{ABOUT 'SAVAGES'}

It is at this point that Arendt introduces her critique of human rights. Her provocative argument in the second half of ch 9, on 'The Perplexities of the Rights of Man', is that the closed system of nation-states that occupies the entire globe produces minorities, stateless people and refugees not just as an excess of nonnationals, but as an excess of non-humans. ${ }^{35}$ The reason is the following. The Declaration of the Rights of Man and the Citizen at the end of the eighteenth century broke with the idea that law emanates from 'social, spiritual, and religious

29 ibid 130, 183, citing Edmund Burke, Reflections on The Revolution in France (1790) 38. See also Luke Gibbons, "Subtilized into Savages": Edmund Burke, Progress, and Primitivism' (2001) 100(1) The South Atlantic Quarterly 83.

30 Arendt, The Origins of Totalitarianism (n 1) 273.

31 ibid 285. Arendt does not discuss the Kurds.

32 ibid 290.

33 ibid.

34 Étienne Balibar analyses this double exclusion. See Étienne Balibar, We, the People of Europe? Reflections on Transnational Citizenship (Princeton University Press 2004), particularly ch 1, titled 'At the Borders of Europe'.

35 On this point, see Étienne Balibar, '(De)Constructing the Human as Human Institution: A Reflection on the Coherence of Hannah Arendt's Practical Philosophy' (2007) 74(3) Social Research 727. 


\section{The Conditions of 'Savages'?}

forces' such as historical custom or divine command. ${ }^{36}$ Instead, this declaration proclaimed the rights of man to be independent and inalienable. The new idea was that human rights were not established by any authority or deduced from any law, that they were not part of 'some larger encompassing order', 37 but that they were inherent in all humans, and that they constituted the foundation of all other laws. Arendt notes that this new idea of human rights emerged at the same time as the idea of popular sovereignty, which was also proclaimed in the name of 'man', rather than, for instance, by the grace of God, like the sovereignty of princes under feudalism. On the basis of these observations, Arendt develops the following argument:

From the beginning the paradox involved in the declaration of inalienable human rights was that it reckoned with an 'abstract' human being who seemed to exist nowhere, for even savages lived in some kind of a social order. If a tribal or other 'backward' community did not enjoy human rights, it was obviously because as a whole it had not yet reached that stage of civilization, the stage of popular and national sovereignty, but was oppressed by foreign or native despots. The whole question of human rights, therefore, was quickly and inextricably blended with the question of national emancipation; only the emancipated sovereignty of the people, of one's own people, seemed to be able to insure them. As mankind, since the French Revolution, was conceived in the image of a family of nations, it gradually became self-evident that the people, and not the individual, was the image of man. The full implication of this identification of the rights of man with the rights of peoples in the European nation-state system came to light only when a growing number of people and peoples suddenly appeared whose elementary rights were as little safeguarded by the ordinary functioning of nation-states in the middle of Europe as they would have been in the heart of Africa. ${ }^{38}$

This passage is the first passage in ch 9 where the terms 'savages' and 'Africa' appear. In the last clause of the first sentence and in the second sentence, Arendt uses free indirect speech to describe the experience of eighteenth century Europeans from their perspective. Arendt argues that it seemed to eighteenth century Europeans that the independent human being that had been declared to be the subject of human rights existed nowhere, because what they called 'savages' would have been the clearest instance of completely isolated human beings, but these Europeans observed that 'even savages' lived in some kind of a social order. Moreover, Arendt argues, eighteenth century Europeans also concluded from their observations of 'savages' that not all human beings enjoyed human rights. According to Arendt, the experience of the tension between the declaration of abstract human rights on the one hand, and the concrete observation of the people they called 'savages' on the other, led to the 'blending' of the question of human rights with the question of national emancipation, by means of a narrative of progress: 'savages' did not yet enjoy human rights because they had not yet liberated themselves, as a people, from despotism, and had therefore not yet reached the civilisational maturity necessary for the enjoyment of human rights.

But if Arendt's reference to 'savages' at the beginning of the passage can be explained as free indirect speech imagining the perspective of eighteenth century Europeans on the concept of humanity, why does she bring up 'the heart of Africa'

36 Arendt, The Origins of Totalitarianism (n 1) 291, citing Declaration of the Rights of Man and the Citizen (France) 26 August 1789.

37 Arendt, The Origins of Totalitarianism (n 1) 291.

38 ibid. 
in the final sentence of this quote? Arendt's reference to the 'heart of Africa' is strange, because her argument in ch 9 is that it is the toxic blending of the question of human rights with the question of national emancipation that produces an excess of non-humans at a time when the nation-state system is beginning to cover the entire globe. What exactly is the connection between this political production of the rightless non-human by European nation-states, on the one hand, and the 'heart of Africa', on the other?

To address this question, I will make a brief detour through ch 7, 'Race and Bureaucracy', in which the terms 'savages' and 'barbarians' make their initial appearance. Arendt argues in ch 7 that two of the elements of totalitarianism, 'race as a principle of the body politic' 39 and 'bureaucracy as a principle of foreign domination', 40 originate in European imperialism. Arendt writes:

Both discoveries were actually made on the Dark Continent. Race was the emergency explanation of human beings whom no European or civilized man could understand and whose humanity so frightened and humiliated the immigrants that they no longer cared to belong to the same human species. ${ }^{41}$

This quote raises the question why Arendt refers to Africa with the cliché, 'the Dark Continent', which she keeps repeating in the pages that follow. In those pages, Arendt repeatedly uses metaphors of light and darkness, for instance when she refers to Joseph Conrad's Heart of Darkness as 'the most illuminating work on actual race experience in Africa', ${ }^{42}$ or when she writes that Leopold II of Belgium was 'responsible for one of the blackest pages in the history of Africa' ${ }^{43}$

One possible answer is that what Arendt is trying to do in these pages is understand the minds of the Europeans in Africa in this period by engaging with a work of fiction in a rhetorically intricate way. Consider, for instance, the following passage, which is similar to the previous passage:

The world of native savages was a perfect setting for [European] men who had escaped the reality of civilization. Under a merciless sun, surrounded by an entirely hostile nature, they were confronted with human beings who, living without the future of a purpose and the past of an accomplishment, were as incomprehensible as the inmates of a madhouse. ${ }^{44}$

Indeed, this passage is immediately followed by a longer quote from Heart of Darkness. According to this interpretation, Arendt is using free indirect speech in order to try to understand a mindset that is by no means her own. ${ }^{45}$ In fact, proponents of this interpretation might insist, her repeated use of the cliché of 'the Dark Continent' and her references to 'savages' — 'Wilden', in her German translation $^{46}$ - is ironic and signals the distance between her own position and

39 ibid 185.

40 ibid.

41 ibid.

42 ibid n 1, citing Joseph Conrad, Heart of Darkness (William Blackwood and Sons 1899).

43 Arendt, The Origins of Totalitarianism (n 1) 185.

44 ibid 190.

45 Cf Anne Norton's argument that: 'Arendt's defenders have argued that she speaks, in The Origins of Totalitarianism, not in her own voice, but in the voice of the Boers'. According to Norton, 'this reading bears witness to the generosity of Arendt's readers, and the loyalty of her friends, but one would be hard put to reconcile this reading with the text'.

Norton (n 4) 253.

46 See Hannah Arendt, Elemente und Ursprünge totaler Herrschaft, Band II: Imperialismus (Ullstein 1975). 
the racist discourse she is trying to understand. According to this interpretation, Arendt sees race and the categories of 'savages' and 'barbarians' exclusively as the products of European racism. Indeed, as George Kateb points out,

if [Arendt] can imagine [the Boers'] feelings when they first saw the blacks, she is also unremitting in describing the Boers' cruelty and their own degeneration into a merely natural, though completely exploitative existence. ${ }^{47}$

However, this interpretation hits its limits precisely in the passages where Arendt compares stateless people and refugees to 'savages' and 'barbarians'. For comparing the rightlessness of stateless people and refugees in Europe to the rightlessness of Africans in no way clarifies the predicament of the former. On the contrary, it raises the big question how the ways in which European nation-states produce the rightlessness of stateless people and refugees relate to the ways in which they produce - and used to produce - the rightlessness of Africans by means of racism; in other words, how the political production of stateless people and refugees relates to the political production of race. Arendt does not address this question.

\section{IV 'A Peculiar State of Nature'}

Let's return to ch 9. The term 'savages' reappears three pages before the end of the chapter:

The survivors of the extermination camps, the inmates of concentration and internment camps, and even the comparatively happy stateless people could see without Burke's arguments that the abstract nakedness of being nothing but human was their greatest danger. Because of it they were regarded as savages and, afraid that they might end by being considered beasts, they insisted on their nationality, the last sign of their former citizenship, as their only remaining and recognized tie with humanity. Their distrust of natural, their preference for national, rights comes precisely from their realization that natural rights are granted even to savages. ... If the tragedy of savage tribes is that they inhabit an unchanged nature which they cannot master, yet upon whose abundance or frugality they depend for their livelihood, that they live and die without leaving any trace, without having contributed anything to a common world, then these rightless people are indeed thrown back into a peculiar state of nature. ${ }^{48}$

Political theorist Ayten Gündoğdu discusses this passage in her 2015 book, Rightlessness in an Age of Rights: Hannah Arendt and the Contemporary Struggles of Migrants, which is a notable exception to the lack of attention to Arendt's 'controversial analogy' between rightless people and 'savage tribes' 49 Gündoğdu writes:

47 Kateb (n 4) 63 (emphasis added). Cf Benhabib's refutation of Anne Norton's critique of Arendt:

[w] hy indeed did Arendt try to analyze the mind of the Boer and leave 'the African silent'? The answer simply is that Arendt analyzed the 'scramble for Africa' from the standpoint of its influence upon the perversion of European morals, manners, and customs; she was concerned to explore how the experience of lawlessness, of civilizational regression, the threat to identity posed by otherness, all return back home from the 'Dark Continent' to create the heart of darkness within Europe itself.

Benhabib, The Reluctant Modernism of Hannah Arendt (n 4) 85-86.

48 Arendt, The Origins of Totalitarianism (n 1) 300.

49 Ayten Gündoğdu, Rightlessness in an Age of Rights: Hannah Arendt and the Contemporary Struggles of Migrants (Oxford University Press 2015). 
One way to read this analogy is to treat it as a sign of Arendt's Eurocentric, even racist, worldview. Accordingly, the analogy indicates that Arendt privileges activities of making, especially cultural fabrication and artistic production, as the measure of civilizational superiority and the standard of humanity. ${ }^{50}$

Gündoğdu reads this interpretation in Jimmy Casas Klausen's article, Hannah Arendt's Antiprimitivism. ${ }^{51}$ However, Gündoğdu argues, Klausen's interpretation mistakenly assumes that Arendt believes in 'essential characteristics of human existence'. ${ }^{52}$ She argues that for Arendt, by contrast,

[a] life without labor, work, and action does not simply cease to be human, but it becomes much more difficult for that life to be recognized as human by others. Read in this way, Arendt's controversial analogy between the stateless and the 'savages' alerts us to the conditions that can stand in the way of such recognition. ${ }^{53}$

However, Gündoğdu's interpretation of Arendt's comparison is unsatisfying. For what makes Arendt's text so valuable for scholars of statelessness and of refugee politics and refugee rights is that Arendt does not focus on 'the conditions that can stand in the way' of being recognised as human, but on the political mechanisms that produce such conditions, that is, on political mechanisms of derecognition and dehumanisation. The questions that Gündoğdu fails to address are: first, what is the connection between the political mechanisms of derecognising/dehumanising some people as non-nationals, on the one hand, and the political mechanisms of derecognising/dehumanising some people as 'savages', on the other? And second, why does Arendt repeatedly compare stateless people and refugees to 'savages'? In fact, Klausen concludes the article that Gündoğdu criticises by gesturing precisely towards these questions:

The greater irony, which is just as tragic as ironic, is that Arendt deploys Hottentots to heighten awareness of the political exclusions generated by the failure of the nation-state system and attendant predicament of rights regimes - yet, for all that, she never turns the analogy around to reevaluate the antiprimitivist exclusions inherent in her own categories. ${ }^{54}$

In the passage cited above, Arendt writes that the greatest danger of camp inmates and stateless people was 'the abstract nakedness of being nothing but human', ${ }^{55}$ and that it is 'because of it' (because of this abstract nakedness) that they were regarded as savages. ${ }^{56}$ However, consider cultural theorist Paul Gilroy's critique of this passage:

Arendt misrecognized the abstractly naked human as the natural or essential human. Instead, that vulnerable figure might be described more accurately and more usefully as a racialised human: a particular, infra-human invention rather than

50 ibid 148.

51 Jimmy Casas Klausen, 'Hannah Arendt's Antiprimitivism' (2010) 38(3) Political Theory 394. See also Gündoğdu's critique of Klausen: Ayten Gündoğdu, 'Arendt on Culture and Imperialism: Response to Klausen' (2011) 39(5) Political Theory 661, as well as: Jimmy Casas Klausen, 'Reply to Gündoğdu' (2011) 39(5) Political Theory 668.

52 Gündoğdu, Rightlessness in an Age of Rights, 148.

53 ibid.

54 Klausen, 'Hannah Arendt's Antiprimitivism' (n 51) 416 (citations omitted).

55 Arendt, The Origins of Totalitarianism (n 1) 300.

56 ibid. 
a specimen of the catastrophically empty humanity that she wished to repudiate. Her error corresponds to a refusal to engage racism critically. ${ }^{57}$

Indeed, it makes much more sense to argue that the greatest danger of camp inmates and stateless people was to be racialised as 'savages'-in-quotation-marks, in a way that ought to be compared to the ways in which colonial subjects were racialised - and put in camps and massacred - as 'savages'-in-quotation-marks.

However, Arendt is unable to make this argument, because she uses 'the conditions of savages' as a paradigmatic example of rightlessness. ${ }^{58}$ The 'tragedy of savage tribes' that Arendt mentions in the final sentence of the passage cited above is that they 'inhabit an unchanged nature which they cannot master', ${ }^{59}$ in other words, that they live in a state of nature, outside the common world of politics established by laws. The tragedy of camp inmates and stateless people, Arendt suggests, is that 'these rightless people are indeed thrown back into a peculiar state of nature'. 60 Thus, according to Arendt, 'savage tribes' and camp inmates and stateless people both live in a state of nature, outside politics, outside a 'world' where law guarantees that their words carry meaning and their actions have consequences. But the difference, Arendt suggests, is that 'savage tribes' live in a state of nature that is somehow natural, the state of an 'unchanged nature', ${ }^{61}$ whereas camp inmates and stateless people are 'thrown back' into a state of nature that is 'peculiar' because it has been artificially produced. ${ }^{62}$

Let us return, one more time, to ch 7, where Arendt describes the European encounter with 'native tribes on the Dark Continent'. ${ }^{63}$ In this passage, she describes these tribes as 'prehistoric', ${ }^{64}$ following a tradition of referring to Africa as outside history familiar from Georg Wilhelm Friedrich Hegel's Lectures on the Philosophy of History: ${ }^{65}$

The word 'race' has a precise meaning only when and where peoples are confronted with such tribes of which they have no historical record and which do not know any history of their own. ... What made [such tribes] different from other human beings was not at all the color of their skin but the fact that they behaved like a part of nature, that they treated nature as their undisputed master, that they had not created a human world, a human reality, and that therefore nature had remained, in all its majesty, the only overwhelming reality - compared to which they appeared to be phantoms, unreal and ghostlike. They were, as it were, 'natural' human beings who lacked the specifically human character, the specifically human reality, so that when European men massacred them they somehow were not aware that they had committed murder. ${ }^{66}$

57 Paul Gilroy, Race and the Right to be Human (Inaugural lecture, accepting the Treaty of Utrecht Chair, Utrecht University, 3 December 2009).

58 Arendt, The Origins of Totalitarianism (n 1) 302.

59 ibid 300.

60 ibid.

61 ibid.

62 ibid.

63 ibid 192.

64 ibid.

65 Norton quotes Hegel's infamous claim that Africa is 'no historical part of the World... What we properly understand by Africa, is the Unhistorical, Undeveloped Spirit, still involved in the conditions of mere nature' and comments, 'This is Arendt's Africa'. Norton (n 4) 252, quoting Georg Wilhelm Friedrich Hegel, Lectures on the Philosophy of History, tr J Sibree (Dover 1956) 99.

66 Arendt, The Origins of Totalitarianism (n 1) 192 (emphasis added). 
It could still be argued that Arendt is simply describing the perspective of 'European men' in this passage: when she refers to "'natural" human beings', she puts the word 'natural' in quotation marks, and adds the qualifier, 'as it were'. ${ }^{67}$ Yet at the same time, Arendt needs the opposition between "'natural" human beings' and humans whose 'specifically human character' consists in having 'created a human world', in order to explain the expulsion from humanity of concentration camp inmates and stateless people. ${ }^{68}$ In the penultimate chapter of The Origins of Totalitarianism, Arendt argues again that there is 'something highly unnatural' about 'human' (in quotation marks) 'nature' (in quotation marks) in general:

Actually the experience of the concentration camps does show that human beings can be transformed into specimens of the human animal, and that man's 'nature' is only 'human' insofar as it opens up to man the possibility of becoming something highly unnatural, that is, a man. ${ }^{69}$

However, all these quotation marks, and Arendt's repeated use of free indirect speech, do not change the fact that, as Michael Rothberg has argued, Arendt does not analyse 'the traumatic nature of the physical and epistemic violence of colonialism as productive of the natural/unnatural humanity opposition' ${ }^{70}$

\section{Thinking the Politics of Countering Statelessness with ARENDT}

\section{AGAINST ARENDT: THE DARK BACKGROUND OF MERE GIVENNESS}

Arendt understood the predicament of stateless people to be that they are excluded from politics. That is, Arendt understood the predicament of stateless people to be that they are excluded from participating as equals in a political space where their speech can appear as meaningful and their actions have consequences, which leaves them without agency and without effective legal protection and thus exposes them to arbitrary force. Yet scholars of statelessness nevertheless keep returning to Arendt, primarily because of Arendt's notion of a 'right to have rights', which gestures towards ways in which a politics of stateless people might not be a contradiction in terms. However, I will argue in this section that thinking a politics of stateless people that is not a contradiction in terms requires a critique of the conception of politics with which Arendt concludes 'Imperialism'.

On the penultimate page of 'Imperialism', Arendt argues that 'our political life' depends, 'since the Greeks', ${ }^{71}$ on a strict separation between the private and the public sphere:

This whole sphere of the merely given, relegated to private life in civilized society, is a permanent threat to the public sphere, because the public sphere is as consistently based on the law of equality as the private sphere is based on the law of universal difference and differentiation. ... Our political life rests on the assumption that we can produce equality through organization, because man can act in and change and build a common world, together with his equals and only with his equals. The dark background of mere givenness, the background formed

67 ibid.

68 ibid.

69 Arendt, The Origins of Totalitarianism (n 1) 455.

70 Michael Rothberg, Multidirectional Memory: Remembering the Holocaust in an Age of Decolonization (Stanford University Press, 2009) 61.

71 Arendt, The Origins of Totalitarianism (n 1) 301. 
by our unchangeable and unique nature, breaks into the political scene as the alien which in its all too obvious difference reminds us of the limitations of human equality. ${ }^{72}$

According to Arendt, the 'all too obvious difference' of the 'alien' provokes hatred, because 'aliens' represent 'the dark background of mere givenness', ${ }^{73}$ which has been relegated to the 'private sphere' by the 'common world' with its 'public sphere', its 'political scene' that is based on the law of equality. ${ }^{74}$ The 'natural' difference of the alien must not become 'all too obvious' in this common world: 75 it must remain in the dark background, not break into the foreground of the political artifice where speech and action among equals is played out. To avoid this rupture, Arendt argues, 'highly developed political communities' such as nation-states or ancient city-states often insist on ethnic homogeneity. ${ }^{76}$

However, Arendt recognises that the political production of equality can go too far:

No doubt, wherever public life and its law of equality are completely victorious, wherever a civilization succeeds in eliminating or reducing to a minimum the dark background of difference, it will end in complete petrifaction and be punished, so to speak, for having forgotten that man is only the master, not the creator of the world. ${ }^{77}$

What, then, is Arendt suggesting here? Is this an argument for recognising a certain 'tragic dimension' in politics and law, an argument that political communities should only aim to contain and disavow, but not eliminate the 'dark background of mere difference', ${ }^{78}$ and that they should learn to live with the fact that the law of equality cannot extend to everyone? Or is Arendt suggesting that there is something fundamentally wrong with a conception of politics that can only recognise people as equal speaking and acting beings if they belong to the same homogeneous group?

'Imperialism' concludes with the former suggestion, and does not pursue the second one, even though the second suggestion would be an obvious continuation of the overall argument of 'Imperialism', which is, as I have shown above, first and foremost a critique of the nation-state and its principle of homogeneity. However, pursuing the second suggestion requires a critique of the categories of 'our political life', ${ }^{79}$ of a conception of politics that opposes the world to nature; the citizen to the barbarian; the civilised to the savage; the territorial to the nomadic; and the European to the African. Arendt's text offers important resources for developing such a critique, especially in its theoretical move to focus on mechanisms of political exclusion and to subject those mechanisms to a genealogical critique. Yet Arendt herself does not go there, because she seems unable to imagine a conception of politics beyond these oppositions.

Consider Arendt's example immediately preceding the passage cited in the previous paragraph:

\footnotetext{
ibid.

ibid.

ibid.

ibid.

ibid.

ibid 302.

ibid 301.

ibid.
} 
If a Negro in a white community is considered a Negro and nothing else, he loses along with his right to equality that freedom of action which is specifically human; all his deeds are now explained as 'necessary' consequences of some 'Negro' qualities; he has become some specimen of an animal species, called man. Much the same thing happens to those who have lost all distinctive political qualities and have become human beings and nothing else. ${ }^{80}$

Arendt's example raises the question what might remedy the racist dehumanisation of blacks by a white community, but she does not answer this question in 'Imperialism'. ${ }^{81}$ In 'Imperialism', Arendt maintains a conception of politics in which people are either equal citizens or abstract figures of mere difference who threaten the political artifice by bringing the "dark background of mere givenness' into the public sphere. However, such a conception of politics obscures the political mechanisms of exclusion that put some people into the latter category, and forecloses a politics of actively confronting and countering these mechanisms. Such a conception of politics can only lament the political production of stateless people, but not imagine a politics of countering their predicament. By contrast, a politics of countering the predicament of stateless people - being forced into the conditions of 'savages' — requires historicising and politicising the mechanisms of exclusion, and starting from the relations that already exist between citizens and stateless people, instead of disavowing them. Such a politics would situate itself within the history of imperialism and postcolonialism, consider the connections between the political production of statelessness and the political production of race, and prominently include a politics of anti-racism.

\section{ThINKING With We ARE Here}

Why, then, is it still so useful to return to Arendt's 'Imperialism' to analyse refugee politics and refugee rights in the present? In this concluding section, I will address this question by discussing the politics of refugee collective We Are Here in Amsterdam. I will first recall the origins of this collective, and then explain why a critical reading of 'Imperialism' is useful for making sense of their politics.

On 4 September 2012, six men set up a make-shift tent in the yard of the Diaconate of Amsterdam, an organisation of the Dutch Protestant Church that

80 ibid 302.

81 In Hannah Arendt, On Violence (Harcourt 1970), Arendt's answer is republicanist: integration into a political community that would consider race irrelevant. In that text, Arendt accuses black protestors challenging the exclusion of blacks from United States universities of seeking to lower academic standards, and laments their demand for curriculum changes by qualifying Swahili ('a nineteenth century kind of no-language') and African literature as 'nonexistent subjects'. Arendt cites with approval a black critic of the protestors' demands who argues that "what Negro students need is "remedial training" so that they "can do mathematics and write a correct sentence", not "soul courses": at 95-96 app VIII. 
supports people in precarious positions. ${ }^{82}$ They put a sign on the tent that read: 'De kerk slaapt buiten' ('the church sleeps outside'). The purpose of the tent was not only to take shelter, but also to make visible the predicament in which they found themselves: their asylum requests had been rejected, but they were unable to return to their presumed home countries, mainly because these countries (such as Somalia) were not safe or because the embassies or consulates of these countries would not cooperate with their return. ${ }^{83}$ Living in the Netherlands after receiving an administrative order to leave, they had become targets of the Dutch state's 'discouragement policy' ('ontmoedigingsbeleid'), which seeks to make the lives of irregularised ${ }^{84}$ people so difficult that they will find some way to return to their country of origin on their own, and to discourage others from coming to the Netherlands in the first place. Initiated in the 1990s with the 1991 connecting of social security numbers to residency status, which made it impossible for irregularised people to work legally; the 1993 Wet op de Identificatieplicht ('Compulsory Identification Act'), ${ }^{85}$ which requires anyone from age fourteen to show a valid identification card when asked by police; and the 1998 Koppelingswet ('Linkage Act') ${ }^{86}$ that links the ability to enrol in health insurance plans and claim social benefits to legal residency, the discouragement policy also seeks to prevent people whose presence has been delegitimised by the state from moving freely (particularly through frequent arrest and detention) ${ }^{87}$ and from taking shelter (in 2007, the Secretary of Justice concluded an agreement with the Association of Dutch Municipalities that tied a one-time amnesty that gave legal residency to a limited group of irregularised people to a stipulation that municipalities would stop providing emergency shelter to irregularised adults; ${ }^{88}$

82 The diaconate was founded in 1578 to provide shelter for orphans and elderly and sick people. It is currently part of the Protestant Church of Amsterdam, and still supports and initiates projects for people in precarious situations: 'Vluchtelingen zetten tentje op in centrum' [Refugees Set up a Tent in Center] AT5 (online, 5 September 2012) $<$ http://www.at5.nl/artikelen/86273/vluchtelingen-zetten-tentje-op-in-centrum>. For a timeline of the first two years of the We Are Here group (in Dutch), see: Jasper Piersma, 'Tijdlijn: de lange tocht van de vluchtingen in Amsterdam' [Timeline: The Long Journey of the Refugees in Amsterdam] Het Parool (online, 29 August 2014) $<$ http://www.parool.nl/amsterdam/tijdlijn-de-lange-tocht-van-de-vluchtingen-inamsterdam $\sim 3731269 />$. The best introduction to We Are Here is: Jonas Staal, We Are Here (eds), New World Academy Reader \#2: Collective Struggle of Refugees. Lost. In Between. (Basis voor Actuele Kunst 2013) 22-23 <www.bak-utrecht.nl>. This reader is an excellent introduction to We Are Here. See also Juan Amaya Castro, 'We Are Here! Undocumented Migrant Activism and the Political Economy of Visibility' in Yolande Jansen, Robin Celikates and Joost de Bloois (eds), The Irregularization of Migration in Contemporary Europe: Detention, Deportation, Drowning (Rowman \& Littlefield 2016).

83 For a juridical discussion of these reasons, see Thomas Spijkerboer, 'Wij zijn hier' [We Are Here] (2013) 1204 NJB, and the response to this article by Ernst Hirsch Ballin, 'Wie zijn wij?' (2013) 1205 NJB. See also Sinead Wendt's meticulously researched and theoretically sophisticated Master's thesis, "No More Bla Bla Bla" (Masters Thesis, University of Amsterdam, 2016) (unpublished).

84 I use this term instead of 'undocumented' to indicate the fact that these refugees have a specific relation to the law that has been actively produced through their exclusion. On this term, see also Jansen, Celikates and de Bloois (n 82).

85 Wet op de Identificatieplicht [Compulsory Identification Act] (Netherlands) Law of 9 December 1993, art 2.

86 Koppelingswet [Linkage Act] (Netherlands) Law of 1 July 1998.

87 See Martijn Stronks, 'The Paradox of Visible Illegality: A Brief History of Dutch Migration Control', tr Renée in der Maur, in Staal and We Are Here (n 82) 65.

88 Michiel Kruijt and Map Oberndorff, 'Akkoord over pardon asielzoekers', De Volkskrant (online, 28 April 2007) <www.volkskrant.nl/nieuws-achtergrond/akkoord-over-pardonasielzoekers $\sim$ bbe $38481 />$. 
furthermore, the 2010 Wet Kraken en Leegstand ('Squatting Law') made squatting a criminal offense). ${ }^{89}$

After another fourteen people who found themselves in the same situation moved into the tent, they decided to relocate and set up a tent camp elsewhere in Amsterdam, on an enclosed former schoolyard off a street that happened to be called the Notweg. (The name Notweg refers to the street's origin as a private road where people other than the owners had a right of way; the likely meaning of the old Dutch word not is necessity, and its contemporary Dutch homophone nood means emergency. The campers would dispute the later eviction order's reference to their camp's location as a public road, arguing that the legal status of the yard was unclear and that it might be legitimately used by those in need). ${ }^{90}$ Over the next couple of months, more than a hundred people joined them; they received tents, food, clothing and medical care from local supporters. At the Notweg, the campers decided to name themselves We Are Here, Wij zijn hier in Dutch. ${ }^{91}$ Although the Mayor of Amsterdam initially allowed the camp to exist as a 'supporting part of the protest', he issued an eviction order two months later, objecting, among other things, to the continuous expansion of the camp and to the fact that the protestors had failed to cooperate with attempts by the Municipal Health Service and the Ministry of Security and Justice's Repatriation and Departure Service to find individual, temporary solutions for their lack of shelter. ${ }^{92}$ Indeed, the point of saying We Are Here, and of demonstrating it through protesting, is for people whose presence has been delegitimised by the Dutch state to show that they are in fact present, that their presence cannot be dismissed as individual, exceptional and temporary problems that will all ultimately be resolved through deportation, and that they can speak and act together in meaningful ways.

Of the 108 people who were arrested for disobeying the mayor's eviction order, 98 were released, or geklinkerd, within twelve hours (the verb klinkeren refers to clinker bricks; it has become a common way of describing the act of putting irregularised people on the street, connoting harshness). ${ }^{93}$ The fact that only two people were ultimately deported — one of them to Italy because, per the Dublin Regulation, ${ }^{94}$ he was only allowed to submit an asylum request in the country where he had first entered the Schengen Zone - testifies to We Are Here's 'undeportability'. ${ }^{95}$ A few days later, they took shelter in an empty church, aided by local squatters. The way in which they named the church and the numerous subsequent squats all over Amsterdam where they have taken shelter since, by adding the word vlucht (flight) to the building's former name or function -

89 Wet Kraken en Leegstand [Squatting Law] (Netherlands) Law of 1 October 2010.

90 Böhler Advocaten, Bezwaarschrift: Ontruiming Tentenkamp Wij Zijn Hier! [Notice of Objection: Evacuation of Tent Camp We Are Here] (Notice, 18 November 2012) $<$ https://www.prakkendoliveira.nl/images/nieuws/2012/121118 _bezwaarschrift_besluit_bw_amsterdam_ontruiming_wij_zijn_hier.pdf $>$.

91 The group has been using both Dutch and English. 'We Are a Political Group', Interview with Yoonis Osman Nuur (Jonas Staal, Warns, 20 August 2013) in Jonas Staal, We Are Here (eds), New World Academy Reader \#2: Collective Struggle of Refugees. Lost. In Between. (Basis voor Actuele Kunst 2013) 27 ('We Are a Political Group').

92 The Municipal Health Service offered to hold 'pre-screenings' with refugees to 'explore individual possibilities' to spend the winter months in different homeless shelters outside Amsterdam; the offer for shelter of the Repatriation and Departure Service was conditional on a willingness to return. Letter from Mayor van der Laan to Böhler Advocaten, 16 November 2012.

93 Spijkerboer (n 83).

94 Regulation (EC) No 343/2003 [2003] OJ L 50/1 ('Dublin Regulation').

95 ibid. 
Vluchtkerk (Flight Church), Vluchtgarage, Vluchtgemeente (Flight Municipality, in a former district council office), Vluchtmarkt, Vluchtschool, Vluchtmandela (after the neighbouring Nelson Mandela Park), to name only a few — is an integral part of their ongoing demonstration.

The mayor's eviction order and the Amsterdam District Court's rejection of We Are Here's legal challenge to this order mention a couple of 'incidents' ${ }^{96}$ One night, an extreme-right organisation named Voorpost ('Outpost'), which was founded in Flanders in the 1970s and pursues the irredentist ideal of a Greater Netherlands for the supposed Dutch volk, shut off the entrance gate to the Notweg tent camp with a thick metal chain, imprisoning everyone inside. On another occasion, several young people hurled insults at the campers and threw bread at them.

What can returning to Arendt's arguments in 'Imperialism' contribute to an analysis of the politics of We Are Here? Arendt considered camps to be the extreme opposite of spaces for politics. Whereas in a political space, speech can appear as meaningful and actions as consequential, in a camp it does not matter what anyone says or does. In a political space, people can appear to each other, 'publicly', as equal speaking and acting beings, whereas camps are non-spaces where no speech or action can appear to any public. ${ }^{97}$ The racist reactions against We Are Here's camp-demonstration aimed at the destruction of politics, by transforming the camp-demonstration into a detention camp and by theatrically treating the demonstrators as zoo animals. In this way, Voorpost and the other group foreclosed political interaction and enforced a racialised distinction between nationals and those designated by the state as illegal.

If Voorpost's reaction to We Are Here's camp was aimed at the destruction of politics, We Are Here's actions can be interpreted as enacting politics where none existed, as an enactment of what Arendt called the right to have rights. In interpreting We Are Here's actions as an enactment of the right to have rights, I follow James Ingram's reading of Arendt's rights politics as an 'active, bottomup' vision of 'the activity of potential rights holders themselves'. ${ }^{98}$ Saying and demonstrating We Are Here can be interpreted as a speech act of insisting that there be a space for politics: against an understanding of 'here' as a space from which the members of We Are Here are excluded as 'illegals', the speech act of saying and demonstrating We Are Here makes a political claim to a 'here' in which this speech act can appear as meaningful and consequential. Indeed, We Are Here has insisted from the beginning that it is a political group. ${ }^{99}$

96 These 'incidents' at the Notweg tent camp are mentioned in the mayor's eviction order and in the Amsterdam District Court's rejection of We Are Here's legal challenge to this order: Rechtbank Amsterdam (2012) AWB 12/5657 BESLU. They mention these incidents to substantiate their claim that the tent camp provided a potential threat to public order, which is one of the legitimations for ending a protest, even though European human rights jurisprudence has held that a potential threat to public order posed by counter protestors obliges governments to protect the protestors, rather than constituting a ground to end the protest.

97 Arendt, The Origins of Totalitarianism (n 1) 297.

98 James Ingram, "What is a "Right to Have Rights"? Three Images of the Politics of Human Rights’ (2008) 102(4) American Political Science Review 401, 411. I also agree with Ingram that although Jacques Rancière opposes his own conceptions of politics and rights to those of Arendt, Rancière's conceptions of politics and rights can in fact be read as extensions of Arendt's framework.

99 See 'We Are a Political Group' (n 91). 
However, if Arendt's categories might allow for such an interpretation of We Are Here's name, interpreting their camp-demonstration, and subsequent squatdemonstrations, as a political enactment of the right to have rights runs up against Arendt's fundamental opposition of politics to what she calls 'the dark background of mere givenness'. ${ }^{100}$ I argued in the previous section that Arendt's opposition of politics to 'the dark background of mere givenness' needs to be critiqued when this 'dark background', and the ways in which it is opposed to the realm of politics, are not merely given, but have themselves been produced by humans. This political production of the 'dark background of mere givenness' includes not only the illegalisation of residence and the discouragement policy's myriad ways of putting people in extremely precarious positions that necessitates a focus on basic bodily needs such as the need for food and shelter, but also the imperialist and post-imperialist relations of exploitation and violence between Europe or the North Atlantic Treaty Organization and the regions of origin of the members of We Are Here in Africa and the Middle East. Indeed, We Are Here has participated in innumerable demonstrations, not just calling attention to their own plight but also protesting such issues as the European Union's 2016 refugee barter with Turkey, arms manufacturing and trading and racism. ${ }^{101}$

Although the racist actions against We Are Here are easily dismissed as isolated incidents by marginal groups, Arendt's critique of the post-imperialist nation-state suggests a more structural explanation of the ways in which militant defenses of the nation, in violent opposition to racialised others, take the place of participation in politics. As I discussed in Part III, Arendt's narrative in 'Imperialism' begins with the limitless expansion of capital, which produces a 'superfluous' 'excess population' within European nation-states that gets exported to the colonies. According to Arendt, the antipolitical mode of existence of this excess population has its origins in Thomas Hobbes's antipolitical, 'bourgeois' philosophy that sees human beings primarily as isolated individuals concerned exclusively with their own biological survival and with furthering their private interests. ${ }^{102}$ But this antipolitical mode of existence manifests itself fully only in the mutually dehumanising encounter of the European excess populations with African colonial subjects, which undermines politics within Europe as well when it gets imported back into the European nation-states.

It is therefore worth recalling that the discouragement policy that I mentioned earlier in this section - an intensification of the political exclusions diagnosed by Arendt in 1951 - was developed in tandem with the 'reforms' and privatisations of the 1990s, which were enacted in the Netherlands by supposedly postideological government coalitions of right-of-center liberal parties and 'Third Way' Social Democrats. The discouragement policy seeks to 'incentivise' people to leave the Netherlands by means of strong negative 'stimuli', but many other policies govern nationals in a similar way: as bodies 'responsible' for reacting to incentives, rather than as speaking and acting citizens. Like the substitution of culturalist or racial identifications for political participation, this substitution of population management for politics suggests that the extent to which the post-

100 Arendt, The Origins of Totalitarianism (n 1) 301.

101 See 'Protest Tegen Racisme in Amsterdam', Hart van Nederland (online, 23 March 2019) $<$ www.hartvannederland.nl/nieuws/2019/protest-tegen-racisme-in-amsterdam-een-sociaalen-economisch-rechtvaardig-nederland/>.

102 Arendt, The Origins of Totalitarianism (n 1) 139-43. 
imperialist nation-state constitutes a space for politics even for its own nationals is an open question.

Indeed, an even more alarming interpretation of the Dutch discouragement policy is that it is not an attempt to keep what Arendt called the 'dark background of mere givenness' invisible to the public eye, in order to prevent it from undermining the law of equality that allows the citizens to speak and act on the political scene, but that it is, instead, a cynical way of making visible the distinction between those who belong to the nation and outsiders whose presence threaten not the equal rights but the privileges of the insiders. If this is the case, countering the political production of the de facto statelessness of the members of We Are Here necessitates not just a politics of inclusion but of anti-racism. Reading Arendt's right to have rights in the broader context of her critique of the nation-state, and confronting her repeated comparison of stateless people to 'savages', can sharpen our analyses of the contemporary production of statelessness, and help imagine a politics of countering it. 